\title{
Ornament Exploration Based on the Beliefs of Sangihe
}

\author{
Alifia Putri Anindita ${ }^{1, *}$, Sabrina Ilma Sakina ${ }^{2}$ \\ ${ }^{I}$ Institut Teknologi Bandung, Indonesia \\ ${ }^{2}$ Institut Teknologi Bandung, Indonesia \\ "Corresponding address: alifiaputrianindita@ students.itb.ac.id
}

\begin{abstract}
Sangihe is located at the tip of North Sulawesi, Indonesia, that borders Philippines maritime territory. Sangihe is rich with traditional culture and in the past, had its own local belief in guardian spirits. The Sundeng religion, or to be exact the Sundeng community, worshipped the spirit of nature. Their tradition and ritual that has been done in the past was influenced by European arrival and has been changed through time. The people of Sangihe also have their own original traditional textile that is called kofo fabric. The fabric was made of manila hemp, or the locals called it hote. The fabric making method itself is already extinct, mainly because of the lack of enthusiasts who want to learn the art of kofo and the uncertainty of the target market.
\end{abstract}

This research used a qualitative approach to visualize the narration of Sundeng beliefs into visual elements for textile ornaments. The expected result of this research is a set of novel motifs, based on narrations about the great three spirits of Sundeng while adhering to the aesthetics of the traditional kofo fabric. To conclude, this study's output is a set of developed ornaments for present textile demands

Keywords: Sangihe, Sundeng, Kofo, Exploration, Ornaments

\section{INTRODUCTION}

\subsection{Background}

Indonesia is a vast nation that owns various cultures based on each region and its own beliefs. Even in clothing, Indonesian has various traditional fabric ornaments with unique regional traits. Among them, there is the Sangihe regency in the province of Sulawesi Utara. The people of Sangihe livelihoods are divided into two types of residences. The people who live on more extensive island farms to exchange goods for their necessities, and the people who live on the smaller island do fishery for a living. They have high mobility, a friendly attitude, and respect the value of rule for living from their ancestor.

Above all, they have their valuable cultures, such as their particular fabric and past religion. Sangihe people have a unique fabric called Kofo fabric that is made of abaca tree fiber. The Kofo [1] fabric is already extinct for reasons such as the making difficulty and the lack of market target. The low market for this fabric was beginning to happen when cotton fabric started to enter Sangihe. Sangihe weaving activities experienced a decline starting in 1889 when the abaka banana trees were cut by the Dutch colonial government's order and replaced with cotton, sugar cane, and tobacco.[1] Sam Pantouw, the creator and product developer of Cofo Indonesia said that $k o f o$ is already extinct.

Kofo fabric is hard and stiff, similar to the Philippines' manila hemp because both were made from the same fiber[1][2], yet it was used as a base for traditional dancing costumes. This fabric has its essential meaning on the ornament and the color. Textile crafts in Sangihe have been produced for a long time for room divider curtains, table mats, fabrics for bedding, and clothes. In the past, outsiders introduced a simple loom tied to the body called gedogan.[1] This weave uses a continuous arrangement of warp threads. In Sangihe the woven thread is made from abaca fiber (Musa textilis or Musa mindanesis), a type of banana in Sangihe language called kofo or hote. This hote plant is also 
known as manila hemp.[2] China, India, and Arabia influence most decorative motifs in such as religious ceremonies and as dowry. The products are used in various activities of human life, Sangihe Indonesian textiles.[3] In addition to clothing, textile tribe knows several fabric coloring techniques that use natural materials around them. Red, purple, brown, using the bark of mangroves (mangroves) and seha or noni (Morinda citrifoia) scattered on the island of Sangihe, the red color comes from sumba. From the evidence of the fabric found through the remaining color effects of the old fabrics, no yellow dyeing technique was found. The colors that appear on old kahiwu are red, purple, brownish, light brown, which are the original colors of the hote.

(a)

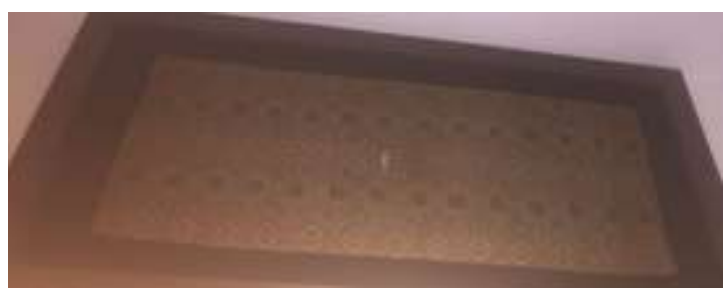

(b)

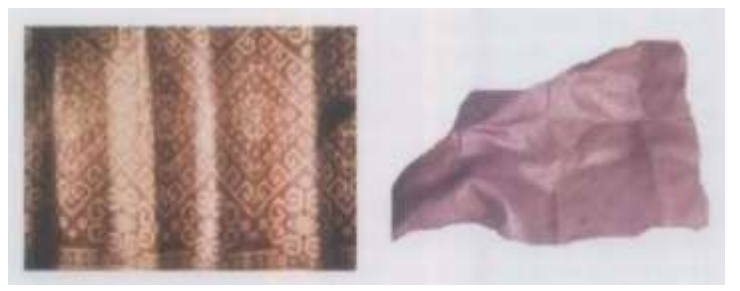

Figure 1 (a) A kofo room divider and handkerchief made approximately 120 years ago[1]; (b) an authentic kofo fabric owned by Cofo Indonesia

Besides that, the Sangihe community has an old belief called Sundeng[1]. This religion is not just a religion; Sundeng is more like a form of society that believes in the greater power. Their great three spirits are Ghenggonalangi, Adittinggi and Mawendo. Ghenggonalangi is the excellent spirit that, as high as the sky, ruled the earth. Adittinggi is the spirit of higher land, and the people of hills worship him. On the other side, Mawendo is the spirit of the sea, and the people of the coast worship him. In the past, the Sundeng community do a sacred ceremony called menali for their spirits. The ceremony is a holy ritual of appreciating the spirit, and it was an off-limit event for their elders. Menali itself was meant to give an offering to the spirits. Their elders are called ampuang, and they do menali in some specific area. Not every village can do the ritual. The participant of menali will form a circle and put the sacrifice in the middle. They sacrifice a human in the early periods, but then the community changed the ceremony into another one called midaroro. The ritual system remains the same, but the offerings switch from human to pig, and now they offer nasi kuning (Indonesian turmeric rice) to another spirit called Himukudi. The alteration is related to the colonial arrival in the district of Sangihe.

The culture of Sangihe, kofo fabric, and Sundeng beliefs are almost being erased from society, even in the local area.[1] The low market for kofo fabric and the spirits of Sundeng has been changed to Himukudi only. For instance, this exploration research is expected to bring the culture to a new light so people can feel them again.

\subsection{Objective}

This research aimed to increase the value of kofo fabric by exploring and designing new sets of ornaments. These ornaments are based on the characteristics of traditional kofo fabric patterns. By analyzing traditional kofo motifs, this research explored the old culture of the Sundeng community so it would not completely disappear from history. The new set of motifs were designed based on the visualized version of the three great spirits of Sundeng's territory: Ghenggolnalangi of the sky, Aditinggi of the higher land, and Mawendo of the sea.

With this exploration research, the writer hopes to help bring up kofo textile products and the extinct Sundeng beliefs.

\subsection{Methodology}

This research methodology utilized visual adaptation strategies[4], which Sunarya utilized several research methodologies that became the primary references for the methods used in writing this paper, namely the visual adaptation strategy in analyzing textile motifs. The primary method to be carried out is to collect data, analyze, then combine the analysis results into new decorative forms for kofo fabric.

The methods used in this research are as the following:

1. For starters, the writer collected data through a literature study.

2. The initial method used in this research is an aesthetic-based qualitative approach with visual elements[5] to identify and decipher 
the aesthetic components in the traditional kofo fabric and clothing, such as color, shape, and origin.

3. An explorative approach is used to combine the characteristics of kofo ornaments and Sundeng old beliefs together through visual adaptation. This method is a strategy to keep the culture alive and prevent them from vanishing entirely in modern society.

The visualized version of Sundeng's three-spirit territory's object variation is planned to be made into abaca fabric ornament design adapted to the current market demand.

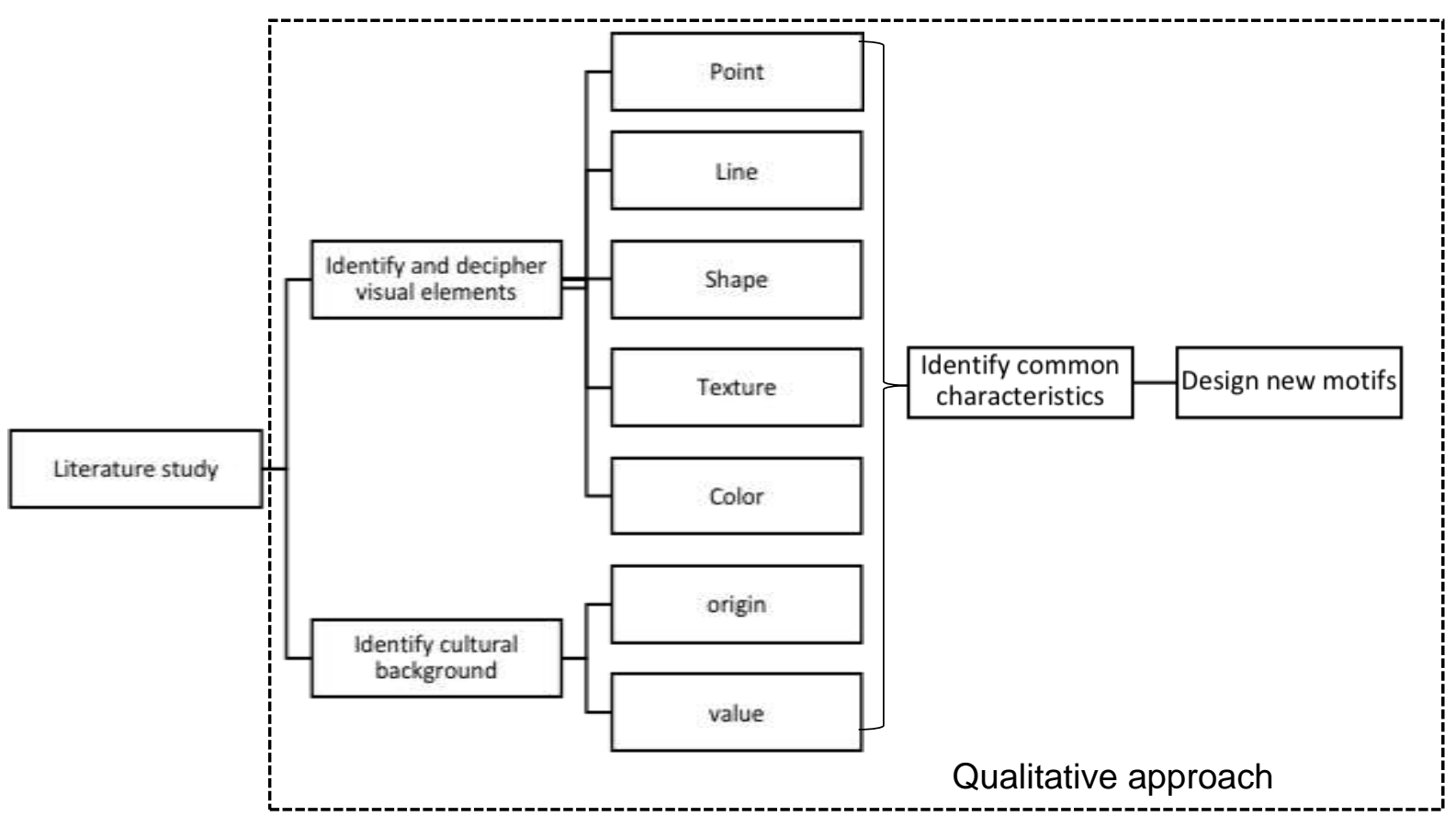

Figure 2 Methodology flow chart

\section{LITERATURE STUDY}

This analysis is written based on the methodology that Sunarya has written in his dissertation summary [4]. The data collected will be described from the name, meaning, the origin of the shape, and its characteristics will be analyzed to create a new form module that does not ignore its authenticity.

\subsection{Identifying kofo's ornament basic shape}

Table 1. Ornament basic shape and meaning [1][7]

\begin{tabular}{|c|c|c|c|c|c|}
\hline No. & Pattern & Name & Meaning & Description & Characteristic \\
\hline 1. & 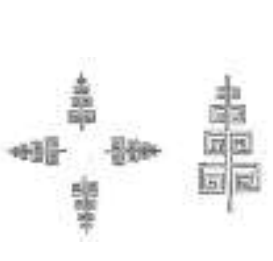 & Sohi & Sharp & $\begin{array}{l}\text { Sohi pattern is an } \\
\text { ornamental variety } \\
\text { in the form of sharp } \\
\text { slices with a basic } \\
\text { rectangular shape. }\end{array}$ & $\begin{array}{l}\text { Spiral } \\
\text { Rectangle } \\
\text { Stacked } \\
\text { Repeated }\end{array}$ \\
\hline
\end{tabular}

The ornament of Sangihe is done modestly and as it is, but it symbolizes strong meaning and highly valuable philosophically. The ornaments of Sangihe Talaud including traditional objects and their culture[6]. Kofo cloth decorations are named in the Sangihe language, such as sohi, isin kemboleng, kakunsi tiwatu, kui, salikuku, malihuge, papaohiang, nalang $u$ anging, nihiabe, taluke, luwu and dalombo. [1] 


\begin{tabular}{|c|c|c|c|c|c|}
\hline 2. & & $\begin{array}{l}\text { Isin } \\
\text { kemboleng }\end{array}$ & $\begin{array}{l}\text { Shark's } \\
\text { tooth }\end{array}$ & $\begin{array}{l}\text { This pattern } \\
\text { symbolizes power } \\
\text { and courage. }\end{array}$ & $\begin{array}{l}\text { Pointed } \\
\text { Each module } \\
\text { made of two } \\
\text { triangles }\end{array}$ \\
\hline 3. & 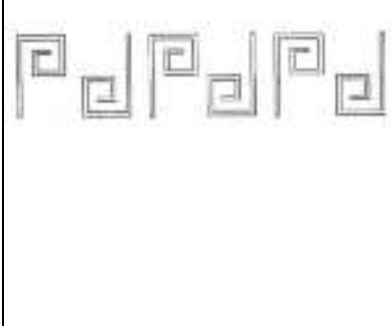 & Kakunsi tiwatu & $\begin{array}{l}\text { Kakunsi : } \\
\text { Key } \\
\text { Tiwatu : } \\
\text { whole, } \\
\text { perfect, } \\
\text { complete }\end{array}$ & $\begin{array}{l}\text { The pattern of } \\
\text { kakunsi tiwatu was } \\
\text { made from the } \\
\text { shape of the key. }\end{array}$ & $\begin{array}{l}\text { Spiral } \\
\text { Rectangle }\end{array}$ \\
\hline 4. & 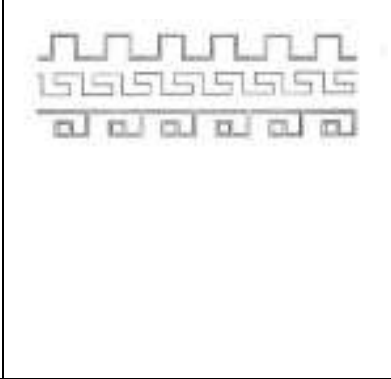 & $\begin{array}{l}\text { Kui / kui } \\
\text { kakandong }\end{array}$ & - & $\begin{array}{l}\text { This ornament } \\
\text { shape was made } \\
\text { from the shape of a } \\
\text { weaving machine } \\
\text { for palm fiber string } \\
\text { made from enau } \\
\text { plant. }\end{array}$ & $\begin{array}{l}\text { Resemble to } \\
\text { rectangle shape }\end{array}$ \\
\hline 5. & $\sqrt{\infty} \mid \sqrt{\infty}$ & Salikuku & $\begin{array}{l}\text { Likuku : } \\
\text { curve }\end{array}$ & $\begin{array}{l}\text { Salikuku indicate } \\
\text { safest, stable, and } \\
\text { steady situation. } \\
\text { Salikuku ornament } \\
\text { was made from the } \\
\text { shape of the fern. }\end{array}$ & $\begin{array}{l}\text { Spiral } \\
\text { Rectangle }\end{array}$ \\
\hline 6. & 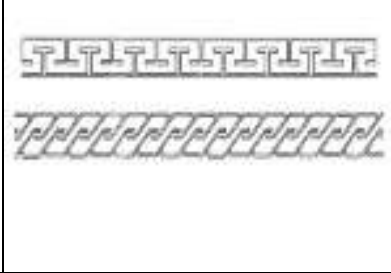 & $\begin{array}{l}\text { Mallhuge } \\
\text { (Taluke } \\
\text { Malihuge u } \\
\text { ginatolang) }\end{array}$ & $\begin{array}{l}\text { Liru : } \\
\text { something } \\
\text { hidden }\end{array}$ & $\begin{array}{l}\text { Malihuge is } \\
\text { originated from liru } \\
\text { word that means } \\
\text { something hidden. }\end{array}$ & $\begin{array}{l}\text { Rigid } \\
\text { Repeated pattern }\end{array}$ \\
\hline 7. & & Papaohiang & $\begin{array}{l}\text { Poahi : } \\
\text { doing here } \\
\text { and there }\end{array}$ & $\begin{array}{l}\text { Papaohiang is } \\
\text { originated from the } \\
\text { word poahi that } \\
\text { means doing here } \\
\text { and there. }\end{array}$ & $\begin{array}{l}\text { Resemble eight- } \\
\text { pointed star } \\
\text { Resemble set of } \\
\text { triangles }\end{array}$ \\
\hline 8. & & $\begin{array}{l}\text { Nalang } \\
\text { anging }\end{array}$ & $\begin{array}{l}\text { The game } \\
\text { of four } \\
\text { points of } \\
\text { the } \\
\text { compass }\end{array}$ & $\begin{array}{l}\text { This pattern was } \\
\text { made from the } \\
\text { shape of a } \\
\text { children's toy made } \\
\text { from coconut } \\
\text { leaves. The leaves }\end{array}$ & $\begin{array}{l}\text { Has four corner } \\
\text { Made from the } \\
\text { basic shape of a } \\
\text { rectangle } \\
\text { Rigid }\end{array}$ \\
\hline
\end{tabular}




\begin{tabular}{|c|c|c|c|c|c|}
\hline & & & & $\begin{array}{l}\text { will spin if it faced } \\
\text { with the wind. }\end{array}$ & \\
\hline 9. & - & Nihiabe & $\begin{array}{l}\text { Hiabe : } \\
\text { seven }\end{array}$ & $\begin{array}{l}\text { The word Nihiabe } \\
\text { combined with } \\
\text { nalang u anging } \\
\text { and Nihiabe mean } \\
\text { seven variations of } \\
\text { stars. }\end{array}$ & \\
\hline 10. & - & $\begin{array}{l}\text { Taluke; } \\
\text { Ghinantolang }\end{array}$ & $\begin{array}{l}\text { Talu } \\
\text { stack, } \\
\text { stacked } \\
\text { Ghinantola } \\
\text { ng/ } \\
\text { ghinantole } \\
\text { : intersect, } \\
\text { touch }\end{array}$ & $\begin{array}{l}\text { Taluke is originated } \\
\text { from talu word that } \\
\text { means stack; } \\
\text { stacked. }\end{array}$ & \\
\hline 11. & $<$ & Lombang & Pattern & - & $\begin{array}{l}\text { Rectangle } \\
\text { Repeated pattern }\end{array}$ \\
\hline 12. & - & Luwu & Soft, soften & $\begin{array}{l}\text { This shape } \\
\text { symbolizes the } \\
\text { gentleness } \\
\text { character }\end{array}$ & \\
\hline 13. & & Dalombo & Fishnet & - & $\begin{array}{l}\text { Resemble the } \\
\text { rectangle shape }\end{array}$ \\
\hline
\end{tabular}

\subsection{Fabric's dye: the source and meaning.}

Besides the ornaments, there is the various traditional color of Sangihe clothing. Each color has its meaning, but the use of color mainly boosts the characteristic of the ornament. The fabric's color also has an essential role in determining the color of the accessories that will balance the overall coordination of the outfit. Beyond its function to give meaning and beautify, color can also attract the market's attention so that its use needs to be considered so that it becomes a new strength for the new ornaments to be formed. Sangihe people frequently use yellow (maririhe), purple (kamumu), red (mahamu), white (ledo), and green (ido) because they are locals' favorites. [1]

Table 2. Fabric's dye [1]

\begin{tabular}{|l|l|l|l|l|l|}
\hline No. & Color (in local language) & Color (in English) & Source & Meaning \\
\hline 1. & Maririhe/ tinong bahu & Yellow & $\begin{array}{l}\text { Processed by } \\
\text { boiling green } \\
\text { leaves. }\end{array}$ & & $\begin{array}{l}\text { Symbolize purity and } \\
\text { greatness. }\end{array}$ \\
& & & & \\
\hline
\end{tabular}




\begin{tabular}{|c|c|c|c|c|}
\hline 2. & Kamumu & Purple & $\begin{array}{l}\text { Made from } \\
\text { mangrove's } \\
\text { bark. }\end{array}$ & Symbolize loyalty. \\
\hline 3. & Mahamu/salaka & Red & $\begin{array}{l}\text { It is processed } \\
\text { by boiling } \\
\text { turmeric tuber } \\
\text { mixed with } \\
\text { kapus plant. }\end{array}$ & Symbolize bravery. \\
\hline 4. & Ledo & White & $\begin{array}{l}\text { This color is } \\
\text { kofo's original } \\
\text { color. }\end{array}$ & $\begin{array}{l}\text { White is the base color of kofo } \\
\text { fabric, and it symbolizes } \\
\text { purity. }\end{array}$ \\
\hline 5. & Ido / melong & Green & $\begin{array}{l}\text { Made by boiling } \\
\text { green leaves. }\end{array}$ & $\begin{array}{l}\text { Symbolize patience and } \\
\text { composure in going through } \\
\text { the hard times. }\end{array}$ \\
\hline
\end{tabular}

\subsection{Potential market preference}

Due to this research's objectives, it is necessary to know attributes of market preference for textile products. Changes in market preferences are crucial. They evolve from people's cultures. Preferences allow consumers to sort products according to their wishes. Based on research conducted by David Sukardi Kodrat in 2021, style and color are included among the attributes that are preferred by the market. [8]

The first is the style attribute which plays an essential role in creating an identity or social market. It also provides to build one's overall self-esteem.[8] The general outfit style is a way of looking to project a person by mood. Style is a fundamental element in fashion design. Style is grouped into two main categories, namely classic and trendsetter. Classic looks that are modish in the long term can be suitable for many occasions and welcomed by the market. On the other hand, the trendsetter is the one that sets the trend. The trendsetter is indispensable for enthusiastic consumers and followers of current trends.

The second is color.[8] It said that color control aesthetics in fashion products and design. It has many roles: conveying messages and moods, building character, deciding target market, appealing attention, and guiding the purchasing decision. The higher-class market prefers premium colors that tend to be dark, neutral, or even colors that give a clean impression.

\section{FINDINGS}

\subsection{The common characteristic of motifs and color}

Through literature study and the analysis of aesthetic elements that have been carried out, the writer found some similarities in the shape, color, and value.

Table 3. Common characteristic

\begin{tabular}{|l|l|l|}
\hline Shapes & Color & Meaning \\
\hline Geometrical & Natural earthen color & Symbolizes courage and bravery \\
Rectangular & & Symbolizes purity \\
Triangular & & Symbolizes faithfulness \\
Rigid & & Symbolizes gentleness \\
Spiral patterned & & \\
Repeated shapes & & \\
\hline
\end{tabular}




\subsection{The inspiration for ornament exploration}

After analyzing aesthetic elements, observation of Sangihe's natural environment is conducted for exploration purpose. Images of Sangihe's environment are taken from Sangihe Stories' account on Instagram

(https://www.instagram.com/sangihestories/) due difficulties reaching the area during the pandemic.

Table 4. Image reference

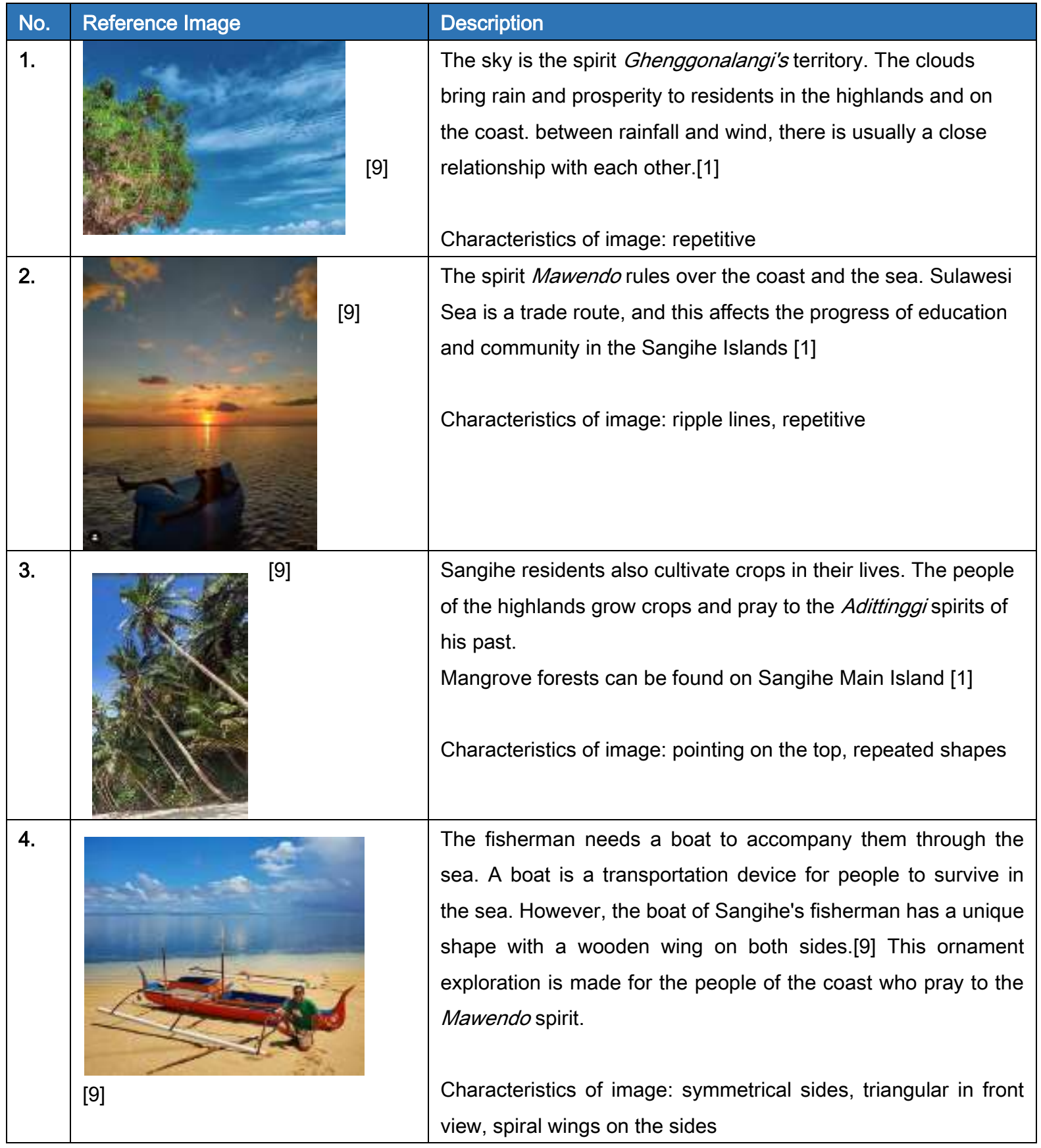




\begin{tabular}{|l|l|l|}
\hline 5. & $\begin{array}{l}\text { The hill is the place for the people who pray to the spirit } \\
\text { Adittinggi. Forests are generally at the top of hills.[1] }\end{array}$ \\
& Characteristics of image: triangular, repeated shapes
\end{tabular}

\section{RESULTS}

From the basic shape of kofo fabric ornaments and the potential market preference, several modules for new textile ornaments composition have been explored, and here are some of them. Exploration of the new forms of ornaments that have been made has been adapted to the characteristics of the actual decorative fabric of kofo fabric so that it does not lose its original nature. The characteristics maintained are that they tend to be geometrically rectangular, triangular, rigid, spiral patterned, and are repeated shapes. The detailed information is written in the table.

Table 5. Exploration module

\begin{tabular}{|c|c|c|c|}
\hline No. & Module & Origin & Description \\
\hline 1. & & Cloud & 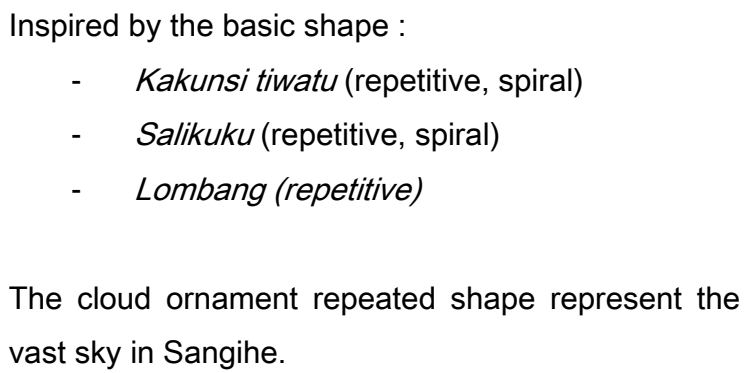 \\
\hline 2. & & Wave & $\begin{array}{l}\text { Inspired by the basic shape: } \\
\text { - Salikuku (repetitive, spiral) } \\
\text { - Kakunsi tiwatu (repetitive, spiral, rectangle) } \\
\text { Wave is the fishermen's company. This ornament } \\
\text { represents the rich ocean of the Sangihe } \\
\text { archipelago. }\end{array}$ \\
\hline 3. & & Tree & $\begin{array}{l}\text { Inspired by the basic shape: } \\
\text { - Sohi (spiral, stacked, repeated) } \\
\text { - Isin kemboleng (triangular points) } \\
\text { The tree brings life to people, so this ornament } \\
\text { represents a fortune for the farmer of Sangihe. }\end{array}$ \\
\hline 4. & & Boat & $\begin{array}{l}\text { Inspired by the basic shape: } \\
\text { - Salikuku (spiral) } \\
\text { The boat is a valuable mobility device for the }\end{array}$ \\
\hline
\end{tabular}




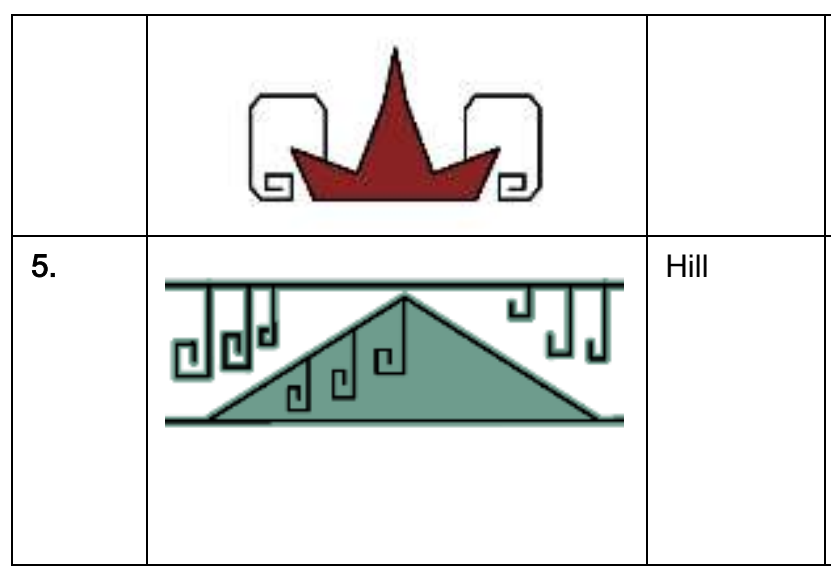

As explained in the previous section, style and color are preference attributes that significantly affect product sales in the market. Therefore, the ornament exploration module is made in a traditional style and muted colors to find a marketing target for the combination of kofo ornaments on abaca fabric.

\section{CONCLUSION}

With this exploratory research, it can be concluded that the primary forms of decoration on traditional kofo fabrics can be updated by adjusting the target market's preferences. A qualitative aesthetic-based approach methodology describes the aesthetic components of traditional kofo fabrics, such as color, shape, meaning, and origin. The result that can be seen is the shape characteristic of the ornament, which is rectangular, triangular, forming a spiral, and repeated horizontally. While in terms of coloring, kofo cloth is usually dyed with boiled plant dyes. The colors used to give color to the fabric have their respective meanings and roles in supporting each other. In terms of fashion preferences, color and style play an important role in smooth marketing. Therefore, these two things become references in exploring the new ornament module. The exploration of the new ornaments has characteristics and refers to the existing kofo ornaments from Sangihe. In addition, the chosen basis is the Sundeng belief which has disappeared from the Sangihe society.

In this exploration research, the writer hopes to bring back the kofo fabric and the Sundeng beliefs that have been extinct. For instance, we can find that this can be achieved by forming an ornament module resulting from exploration by combining the characteristics of the ornamental variety and market preferences. Thus, for the following research opportunity, new possibilities may arise to use the
Sangihe people. This ornament module is made in the hope for the Sangihe fishers to come home safely.

Inspired by the basic shape :

- Malihuge (rigid, repetitive)

- $\quad$ Papaoihang (resemble to set of triangles)

The land is people's home-the people of the hill pray to the great Aditinggi.

exploration module that has been formed in this study to become the business capital of the local population in the development of patterned abaka cloth.

\section{ACKNOWLEDGMENTS}

I am very thankful for the research financial support provided by LPPM ITB (Lembaga Penelitian dan Pengabdian kepada Masyarakat Institut Teknologi Bandung) through its 2021 PPM ITB grant.

\section{REFERENCES}

[1] Steven S. Kain Tenun Traditional "KOFO" Di Sangihe. Jakarta: Direktorat Tradisi, Direktorat Jenderal Nilai Budaya, Seni dan Film, Kementrian Kebudayaan dan Pariwisata, 2011.

[2] Johannes Aldrin T. Laporan Penelitian Pola Pembiayaan (Lending Model) Budidaya Pisang Abaca (Musa textilis nee) di Daerah Essang dan Sekitarnya, Kabupaten Kepulauan Talaud. Management Department, Faculty of Economics, Unika De La Salle, Manado, 2012.

[3] Suyani. Pengaruh Budaya Asing Terhadap Perkembangan Batik Pekalongan in CORAK Jurnal Seni Kriya Vol. 2 No.1, Institut Seni Indonesia, Yogyakarta, 2013.

[4] Yan Yan S. Strategi Adaptasi Visual pada Ragam Hias Batik Sunda. Institut Teknologi Bandung, 2014.

[5] Sadjiman Ebdi S. Nirmana; Dasar-dasar Seni dan Desain, Jalasutra, Yogyakarta, 2009. 
[6] Steller, K.G.F \& Aebesold, W.F.S. Nederlands Woor den Book Met Nederlands Sangirees Register, Martinus Nijhoff, Leiden, 1959.

[7] Walukow A. Kebudayaan Sangihe. Sangihe: Tulisan dalam Sayembara Tulisan Sejarah Sangihe, Dinas Pendidikan Nasional, 2009.

[8] Jannah, I. N., \& Kodrat, D. S. Analysis of the consumer preferences of attributes of Rajini Modest Fashion Products. KnE Social Sciences, 5(5), 2021, pp. 93-103.

[9] Sangihestories on Instagram. [Online]. Available:

https://www.instagram.com/sangihestories/, 2021. 